\title{
Effectiveness of Modeling Learning Strategies to improve Student Learning Outcomes
}

\author{
Emilda Sulasmi \\ Universitas Muhammadiyah Sumatera Utara, Indonesia \\ emilda@umsu.ac.id
}

\section{Abstract}

This study aims to analyze the learning process at SMP Negeri 14 Medan. This research uses qualitative research, with a case study approach of SMP Negeri 14 Medan. Data collection techniques used in this study were observation, interviews, focus group discussions and documentation and then analyzed descriptively with descriptive analysis model. The results obtained are that the modeling learning strategy has a good impact on improving student learning outcomes, by making several figures into models who practice certain materials in the learning process, so that learning to dance starts from opening, core activities to closing. The conclusion of this research is that the modeling learning strategy designed by SMP Negeri 14 Medan, the modeling learning strategy takes into account the interests of students, the learning outcomes taught with modeling learning strategies are higher than those taught with conventional learning strategies.
Keywords

learning strategies,

modeling, learning

outcomes

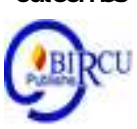

\section{Introduction}

With regard to learning strategies, the teacher has a strategic role in designing a strategy, technique, or approach that is deemed appropriate to achieve learning objectives (Sulasmi, 2020a). As a designer in learning, the teacher plays a very important role in determining the success or failure of achieving learning objectives. In order for learning objectives to be achieved, teachers are required to have skills and be able to organize materials in such a way that learning materials become interesting and challenging. However, currently there is a tendency that teachers often use learning techniques that do not foster the potential for thinking, attitudes and skills of students. Somantri (2001) suggests that the use of such learning techniques is caused by several factors, namely, the habit of learning techniques that have been institutionalized for a long time and these learning techniques are the easiest to do.

In fact, even though the learning objectives have been clearly and clearly defined, the implementation of learning often fails. This indicator can be seen in the low quality of education in Indonesia. And the results of several studies show that graduates of Elementary School (SD), Junior High School (SMP), and Senior High School (SMA) only control about 30 percent of educational material (Azari, 2000).

The process of providing education which is still dominated by the view that knowledge as a set of facts that must be memorized will clearly provide unsatisfactory learning outcomes, due to various things, including the selection of inappropriate learning strategies (Sulasmi, 2020c). To obtain learning outcomes that are in accordance with learning objectives requires the ability to choose the right learning strategy, because learning strategies are the most important thing that must be considered in a teaching and 
learning process (Gunawan \& Sulasmi, 2020; Sulasmi, Agussani, \& Tanjung, 2020). The learning strategy chosen should be adjusted to the methods, media and other learning resources that are considered relevant in conveying information, and guide students to be optimally involved, so that students can gain learning experiences in order to develop their abilities, such as: mental, intellectual, emotional, and social and skills or cognitive, affective and psychomotor (A. Akrim, 2018; Sulasmi \& Akrim, 2020). Thus, the selection of appropriate learning strategies can generate and encourage student activities to improve students' abilities and understanding of certain subject matter.

This phenomenon was found in this research. SMP Negeri 14 Medan, has advantages and uniqueness in managing the learning process, which designs daily learning to achieve the expected learning outcomes, learning which is applied at SMP Negeri 14 Medan by applying modeling learning strategies. By paying attention to the right learning strategy and also the right approach for all students, it can improve the quality of better Islamic education in Islamic education institutions (SF Shah, SR Ghazi, 2015).

Based on the description above, it can be seen that to obtain the expected learning outcomes, a learning strategy is needed that is able to further empower students in a teaching and learning process. Therefore, it is necessary to hold an assessment and renewal (innovation) in the learning strategy using modeling. By learning through modeling, students can observe objects or objects directly which models that are imitated become, admired, and trusted by students so that they represent the actual objects or objects they expect. Objects or objects that are used as models reflect or represent an actual object or object, and that is what students observe and understand (WS, 1989).

Based on this, the scope and formulation of the problem in this study are "How can modeling learning strategies improve learning outcomes at SMP Negeri 14 Medan?" And the purpose of this research is to analyze descriptively modeling learning strategies in improving learning outcomes at SMP Negeri 14 Medan.

\section{Review of Literatures}

Learning is a stage of changing dynamic individual behavior as a result of experiences and interactions with the environment that involve cognitive processes (A. Akrim, 2020; Sulasmi, 2020b). The essence of learning in terms of results is a change in behavior due to the interaction between stimulus and response. Meanwhile, learning in terms of the process aspect is a process of meaning new information by linking it to existing information structures (Gafar and Jamil, 2003).

Learning is a mental activity that takes place in active interaction with the environment, which results in changes in knowledge, understanding, skills and attitudes (Winkel, 1996). Learning outcomes show the level of students' abilities in following a learning process. Therefore, Sunarya, (1983) said that learning outcomes are the result of changing abilities which include cognitive, effective and psychomotor abilities.

From this statement it can be said that learning outcomes are student abilities which indicate an increase in skills acquired from the learning process based on this indication, Wordworth and Marguis (1962) say that learning outcomes are actual abilities that can be measured directly through tests.

Furthermore, the things that are included in the teaching conditions are the characteristics of the teaching content, teaching constraints and various other conditions in the teaching process. From this opinion, it can be seen that learning outcomes are influenced by many factors that relate directly or indirectly to the teaching and learning process. 
Regarding the types of abilities that are products of learning outcomes, Gagne (1977) classifies learning outcomes into five types: (1) intellectual skills, (2) cognitive strategies, (3) verbal information, (3) motor skills, and (4) ) attitude.

However, all these abilities must be relevant to the stated teaching goals. This illustrates that the learning outcomes include two areas, namely the cognitive and psychomotor areas. The results referred to in this study only cover cognitive aspects which consist of six aspects, namely: knowledge, comprehension, application, analysis, and evaluation (Bloom, 1976). This cognitive aspect according to Popham (1981) can be measured through a written test.

In order for students to gain success in their learning outcomes, Deporter, Reardon and Novri (2002) state that there are three steps that teachers must take in learning, first when introducing the content of the lesson the teacher must present multisensory, break information into parts, and repeat frequently. . Second, make small groups of learning greetings to strengthen learning. Third, in giving assignments, involve students individually. From this opinion, one thing can improve learning outcomes as well.

In addition to several indications of learning outcomes that have been conveyed, Reigeluth (1983) in general has also categorized 3 (three) indicators of learning success, namely: (1) learning effectiveness, which is usually measured by the level of success (achievement) of students from various angles, (2) learning efficiency, which is usually measured from the learning time of the learning discussion, and (3) the attractiveness of learning, which is always measured by the tendency of students to learn continuously. In particular, learning outcomes according to him is a performance (performance) which is indicated as an (ability) that is obtained.

Weiner (Gradler, 1991) states that the effort for students themselves to succeed in learning is one of determining success or not. Therefore, in learning the teacher needs to arouse student efforts through certain assignments or activities in learning that can foster certain student efforts in learning that can foster students' efforts in understanding learning material. One way is to give students assignments to make a summary of the learning material that has been studied.

From the above description, it can be stated that the "process" must enable a "learning process" which allows the acquisition of good "learning outcomes" and there is a close relationship between the three.

In general, strategy has the meaning of a direction for action in an effort to achieve the goals that have been found. Associated with teaching and learning, strategies can be interpreted as general patterns of teacher-student activities in the realization of teaching and learning activities to achieve the goals outlined.

Heinich (1996) argues that learning is an arrangement of information and an environment that facilitates learning. Through the environment each student does not only need methods, media and other equipment to convey information, and guide himself to learning. Thus learning can be interpreted as an effort that is done deliberately by using methods, media and other equipment, so that students find it easier to learn the material. This learning condition is carried out based on certain learning strategies. The teacher in choosing a learning strategy appropriately will affect the success in implementing learning activities or the learning process for which he is responsible.

This is because the learning process is a context of interaction between teachers and students. This context should allow optimal student involvement, so that students gain learning experiences in order to develop their abilities (mental; intellectual, emotional, and social as well as skills or cognitive, affective and psychomotor) through learning activities that are deliberately engineered by the teacher. In the context of such interaction it is 
implied about learning outcomes in the learning process. Basically, the learning process refers to events that allow student learning activities to occur in order to achieve the results or objectives that have been applied.

Humans have experienced many developments in various fields due to the human ability to learn, which is experiencing changes, from birth to adulthood. In human life, there are two types of learning, namely learning physically, and learning psychologically or socially, in which a person learns his role and the role of others in social contact (Sarwono, 2001). Through learning in the social process, students will adjust their behavior according to the social roles they have learned. A very important way of social learning is modeling learning (Abduloh et.al, 2020.

A model is a graphic representation of a process, and / or narrative, by showing its main elements and structures (Miarso 1987). Models according to Good and Traves in Miarso (1987) are real-world abstractions or representations of complex events or systems, in the form of narrative, mathematical, graphic or other symbols. It is also stated that a model can be used to imitate, show, explain, predict or introduce something. Gustafson (1984) describes the function of the model as a means to facilitate communication, or prescriptive regular instructions (algorithms) for decision making, or planning guidelines for management activities.

Bandura and Rosenthal in (Gredler, 1994) state that a model is a collection of stimuli arranged in such a way that a person can reap the essence and influence the main information brought about by environmental events without the need to show visible actions. The main goal in the learning process using modeling is a person's ability to imitate the behavior of the model, through a process of observation, it can be decided which behavior will be imitated and implemented in that person.

\section{Research Methods}

The location of this research is SMP Negeri 14 Medan. The time specified in conducting this research is the 2019/2020 school year. The reasons for choosing the research location are; 1) SMP Negeri 14 Medan has implemented various learning strategies, 2) has teachers who are competent to develop learning, 3) has a learning method that is suitable for all students, 4) many achievements include: 1st place in Medan City Level Achievement School in 2013, Award Award from Dina Pendidikan Kota 2016, 5) having relatively adequate and representative facilities.

This type of research is qualitative research with a case study approach, which is characteristic: describing data, analyzing, and interpreting phenomena captured in field observations at SMP Negeri 14 Medan.

This qualitative research is field research, which is research that collects data and information on circulating trains directly to the location or object to be studied, namely SMP Negeri 14 Medan. The basic data in this study is the daily learning flow conducted by SMP Negeri 14 Medan based on integrated education.

The main informants of this research are the principal as the policy controller, the coordinator of integrated education as the person in charge, and the teaching staff as the implementer of integrated education. How to determine informants using purposive techniques and key respondents in accordance with the research objectives. The main informant is expected to be able to provide learning learning data with a modeling learning strategy.

The data collection techniques used in this study were: 1) observation, the researcher observed the day flow process designed and implemented by the teacher in the learning 
process based on modeling learning strategies, 2) interviews, to the principal, as well as educators and education (teachers and staff). ) SMP Negeri 14 Medan as the main respondent for researchers to get information about modeling learning strategies, 3) Focus Group Discussions (FGD), the researchers joined the staff and teachers of SMP Negeri 14 Medan in focus group discussions, which were conducted every day after the activity learning to teach in schools.

The data analysis technique in this study used the Interactive Analysis model of Miles and Huberman. This interactive analysis model consists of four main things, namely: (1) data collection; (2) data condensation; (3) displaying data, and; (4) conclusion: draw / verify. (Miles, MB \& Huberman, AM) Qualitative Data Analysis: An expanded notebook 2nd ed.). The four activities are activities that are intertwined before, during, and after collecting data in parallel form to build general insights called analysis. The data obtained are generally in the form of words, the results of the research analysis are presented in descriptive form.

In qualitative research, data validity testing can be achieved by triangulating data and informants. This means that the researcher has to clarify the findings of a third person, or the same person at different times. If information is received, either by other people or the same person, but at different times still produce the same information, the data is declared "saturated". It was then that the validity and reliability of the research data had been achieved (Idrus, 2009).

\section{Results and Discussion}

The learning steps used modeling in the form of: (1) seeing the model's behavior that should be imitated by students; (2) determine the functional value of the behavior and model; (3) developing a learning sequence; (4) applying learning to guide cognitive processes and motor reproduction processes of students. The implementation of learning focuses on the effect of modeling with a gradual and simple learning process leading to complex skills so that it is easy to identify students' talents, interests and abilities. The basis for learning occurs is the relationship between students and the model as well as reinforcement and punishment and observation. Through reinforcement and punishment received by students, either directly or indirectly, it can shape the expected behavior of students and eliminate unexpected behavior. To provide reinforcement and punishment, teachers must pay attention that giving reinforcement and punishment should not be excessive because students can lose self-control. In addition, reinforcement and punishment given to students through modeling is very helpful for teachers in improving student learning outcomes. Reinforcement provides a functional value of behavior to students about the positive consequences of the task they have completed, while punishment provides a functional value of behavior on the negative consequences received by students if they do not complete the assignment.

The virtue of learning by using modeling is that in designing learning, the teacher can determine which behavior choices will be carried out from the model and adjust the type of model to be used according to student characteristics and the subject matter and the results of the behavior that will be mastered by students after participating in a learning activity unit. In addition, students are more democratic in choosing which behavior to imitate from the model. In learning using teacher role modeling as a guide and motivator, then the teacher provides assistance and explains the learning process being taken, invites students to think critically, analytically, reflectively, openly and be able to develop 
students' abilities through learning experiences, so that the element of joy of selfexpression can be created and planned by the teacher.

By learning through modeling students become more active and creative, remembering that learning will be more meaningful if cognitive, affective, and psychomotor functions can work together. In modeling students learn by watching and observing the model's behavior. Learning support materials are also very much and are found around students. Therefore, teachers can plan learning activities inside and outside the classroom.

Student learning progress using modeling is assessed from the learning process and learning outcomes tests. Students who get high learning outcomes will become models for students who get low learning outcomes. Thus, students will get learning outcomes by observing every action carried out by the model. Finally, these attitudes and behaviors become a part of him. High and low learning outcomes have an impact on self-confidence, his hopes and dreams.

The learning steps use modeling in the form of: (1) seeing and observing models or objects that should be imitated or used as examples by students; (2) determine the functional value of the model or object used as an example; (3) developing a learning sequence; (4) applying learning to guide cognitive processes and motor reproduction processes of students. The implementation of learning focuses on the influence of modeling with the learning process taking place in stages from simple to complex skills so that it is easy to identify students' talents, interests and abilities. The basis for learning is the relationship between the student and the model, and the reinforcement and punishment of observation. Through reinforcement and punishment received by students, either directly or indirectly, it can shape the expected behavior of students and eliminate unexpected behavior. To provide reinforcement and punishment, teachers must pay attention that giving reinforcement and punishment should not be excessive because students can lose self-control. In addition, reinforcement and punishment given to students through modeling really helps teachers in improving student learning outcomes. Reinforcement provides a functional value of behavior to students about the positive consequences of the task they have completed, while punishment provides a functional value of behavior on the negative consequences received by students if they do not complete the assignment.

Based on the results of the research conducted, it can be seen that the learning outcomes of students who are taught with the modeling learning strategy obtain an average score of 18.87 and the average score of conventional learning is 18.25 . From the difference in the average score and the results of hypothesis testing, it is evident that the learning outcomes of students who are taught using modeling learning strategies are higher than students who are taught using conventional learning strategies.

If you pay attention to the sequence of the learning steps of the two learning models above, it can be seen that the learning outcomes of students who are taught using modeling learning strategies are higher than conventional learning strategies. The virtue of learning by using modeling is that in designing learning, the teacher can determine which characteristics or behavior choices will be carried out from the model or object that is used as an example and adjusts the type of model to be used according to student characteristics and the subject matter and what behavior results will be. controlled by students after participating in a unit of learning activities.

Modeling learning can improve students' mindset to behave and act more democratically in choosing which characteristics / behavior to imitate from the model. Through this modeling learning the teacher can stimulate and direct students to think 
critically, analytically, reflectively, and openly, which in turn greatly affect their learning outcomes. These findings support the results of research by Evi Susilawati (2005) which states that the modeling learning model can encourage students to behave and act scientifically, and provide learning experiences that enable students to engage physically, emotionally, and mentally in learning activities so that there are differences in learning outcomes of PPKn students who are taught using modeling and conventional learning models. It is further argued that the PPKn learning outcomes of students who are taught with the modeling learning model are higher than the conventional learning model.

Furthermore, Usmaidar (2007) argues that in modeling learning, students learn by watching and observing the model's behavior. There are many supporting materials for learning and are available around the students. Therefore, teachers can plan learning activities inside and outside the classroom. The teacher acts as a guide and motivator, where the teacher provides assistance and explains the learning process undertaken, invites students to think critically, analytically, reflectively, openly and is able to develop the abilities students have through learning experiences, so that the element of joy from selfexpression can be created and planned. by the teacher. By learning through modeling students become more active and creative, remembering that learning will be more meaningful if cognitive, affective, and psychomotor functions can work together. The results of this study support Sopah's research (1999) which states that the ARIAS learning model is a learning model that can foster students' attention, confidence, activity, and fun, so that the learning outcomes of students who are taught with the ARIAS learning model are higher than non-learning models. -ARIAS.

Based on the description above, the following describes the differences between modeling learning strategies and conventional learning strategies:

Table 1. Differences in Modeling Learning Strategies with Conventional

\begin{tabular}{|c|c|c|}
\hline No & Learning Strategies Modeling & Conventional Learning Strategies \\
\hline 1 & Learning through models & Learning through understanding \\
\hline 2 & $\begin{array}{l}\text { Teachers can plan learning inside } \\
\text { and outside the classroom } \\
\text { environment }\end{array}$ & $\begin{array}{l}\text { Teachers can plan lessons only in } \\
\text { the classroom environment }\end{array}$ \\
\hline 3 & $\begin{array}{l}\text { The elements of joy and self- } \\
\text { expression in learning can be } \\
\text { created and planned }\end{array}$ & $\begin{array}{l}\text { The elements of joy and self- } \\
\text { expression in learning, if any, } \\
\text { happened by chance }\end{array}$ \\
\hline 4 & $\begin{array}{l}\text { Gradual process, from simple to } \\
\text { complex skills }\end{array}$ & $\begin{array}{l}\text { The learning process starts from the } \\
\text { whole }\end{array}$ \\
\hline 5 & Learning by using models & Learn without using models \\
\hline 6 & $\begin{array}{l}\text { The basis for learning is the } \\
\text { relationship between students and } \\
\text { the model and the provision of } \\
\text { reinforcement and punishment from } \\
\text { observations }\end{array}$ & $\begin{array}{l}\text { The basis for learning is perception } \\
\text { as the key to understanding in } \\
\text { learning }\end{array}$ \\
\hline 7 & $\begin{array}{l}\text { It is easy to identify students' } \\
\text { talents, interests and abilities }\end{array}$ & $\begin{array}{l}\text { It is difficult to identify students' } \\
\text { interests and abilities }\end{array}$ \\
\hline
\end{tabular}

Student learning progress using modeling is assessed from the learning process and learning outcomes tests. Students who get high learning outcomes will become models for students who get low learning outcomes. Students obtain learning outcomes by observing every action the model carries out. Finally, these attitudes and behaviors become part of 
him, the high and low learning outcomes have an impact on self-confidence, his hopes and dreams.

While the learning strategy using the conventional approach is a teacher-oriented learning approach, meaning that the teacher is the only source of information and knowledge for students (teacher center). This learning strategy is teacher-oriented and usually lectures are the main choice of learning methods. Conditions like this will result in students being less empowered in finding the knowledge they need, so that students acquire the knowledge and knowledge based on what the teacher just says. In line with this opinion, the findings of Nawawi (2004) suggest that the conventional learning model is a learning model in which the learning strategy uses the teacher as the only learning source, meaning that the teacher is in control and control in determining the content, methods, and assessing student learning outcomes.

Furthermore, learning with a conventional approach does not encourage a sense of curiosity and a sense of responsibility for students in planning and organizing their learning methods. As a result, the knowledge and skills possessed by students are only in short-term memory, and will tend to be unable to increase students' retention of their subject matter. In this learning, communication that takes place in the one-way learning process tends to cause students to misunderstand certain concepts and terms,

Dick and Carey (2006) argues that conventional learning strategies tend to use rote memorization and focus more on the memory aspect, which emphasizes the memory element, so that students acquire knowledge and skills by connecting words with subjects repeatedly, which in the end if students have not memorized it perfectly, then the material cannot be continued or added. In this strategy, teachers who play a greater role means that students are not directly involved in finding and finding important learning materials, so that the knowledge and skills acquired are not able to increase student retention and memory or are only in short-term memory. Finally, student success in learning is highly dependent on teacher delivery, abilities, and teacher experience alone. Learning like this will have the potential to provide less than optimal learning outcomes.

From the description above, it can be understood that the learning outcomes of students who are taught with modeling learning strategies are higher than conventional learning strategies. To strengthen this finding, the learning outcomes data are described as follows:

a) Learning outcomes using a modeling strategy

Table 2. Result Frequency Distribution for Treatment Modeling Learning Strategies

\begin{tabular}{|c|c|c|c|}
\hline Number & Interval Class & $\begin{array}{c}\text { Absolute } \\
\text { Frequency }\end{array}$ & Relative Frequency \\
\hline 1 & $9-12$ & 3 & $7,50 \%$ \\
\hline 2 & $13-16$ & 14 & $35,00 \%$ \\
\hline 3 & $17-20$ & 8 & $20,00 \%$ \\
\hline 4 & $21-24$ & 8 & $20,00 \%$ \\
\hline 5 & $25-28$ & 7 & $17,50 \%$ \\
\hline \multicolumn{2}{|c|}{ Total } & $\mathbf{4 0}$ & $\mathbf{1 0 0 \%}$ \\
\hline
\end{tabular}

Data from table-2 above, it can be seen that there are about $42.50 \%$ of the score of learning outcomes for the treatment of modeling learning strategies is below the average, $20.00 \%$ is the same as the average, and $37.50 \%$ in above average. 
b) Learning outcomes using conventional strategies

Table 3. Frequency Distribution of Learning Outcomes for the Treatment of Conventional Learning Strategies

\begin{tabular}{|c|c|c|c|}
\hline Number & Interval Class & $\begin{array}{c}\text { Absolute } \\
\text { Frequency }\end{array}$ & Relative Frequency \\
\hline 1 & $12-14$ & 4 & $10.00 \%$ \\
\hline 2 & $15-17$ & 6 & $15.00 \%$ \\
\hline 3 & $18-20$ & 16 & $40,00 \%$ \\
\hline 4 & $21-22$ & 12 & $30.00 \%$ \\
\hline 5 & $23-24$ & 2 & $5.00 \%$ \\
\hline \multicolumn{2}{|c|}{ Total } & $\mathbf{4 0}$ & $\mathbf{1 0 0 \%}$ \\
\hline
\end{tabular}

Data from Table 3 above, it can be seen that there are about $25.00 \%$ of the learning outcome scores for the treatment of conventional learning strategies that are below the average, $40.00 \%$ are the same as the average, and $35.00 \%$ are above average.

\section{Conclusion}

Some conclusions from the results of this study are; 1) the modeling learning strategy designed by SMP Negeri 14 Medan is the characteristic of a superior SMP; 2) the modeling learning strategy takes into account the interests of students 3) the learning outcomes taught with modeling learning strategies are higher than those taught with conventional learning strategies, 4) SMP Negeri 14 Medan can be used as an example by other educational institutions with the same to further improve the quality of learning in junior high school formally.

\section{References}

A. Akrim. (2018). Ilmu Pendidikan dalam Persfektif Islam. In Bildung. Yogjakarta: Bildung.

A. Akrim. (2020). Menjadi Generasi Pemimpin. Apa yang Dilakukan Sekolah?

Abduloh, O. A., Juhadi, A. S., Mohammad Syaifuddin, B. E., Wahid Wachyu Adi Winarto, N. A., Mubtadi, W., Hendri Hermawan Adinugraha, A. P., ... \& Muhammad Masruri, N. A. (2020). Effect of Organizational Commitment toward Economical, Environment, Social Performance and Sustainability Performance of Indonesian Private Universities. PalArch's Journal of Archaeology of Egypt/Egyptology, 17(7), 6951-6973.

Bahri, S., Sabrina, R., \& Sulasmi, E. (2020). Mediating Effect Of Work Engagement Between The Relationship Of Self-Efficacy, Career Identity, Work Environment And Job Embeddedness. Journal of Security \& Sustainability Issues, 10(2).

Sulasmi, E. (2020a). Evaluation of Coaching Students Based on Dormitory Curriculum in Madrasah Aliyah Negeri Insan Cendikia Bengkulu Tengah. 640-646.

Dahar, Ratna, W. (1989). Teori-teori Belajar. Jakarta: Erlangga.

Davies, Ivor K. (1991). Pengelolaan Belajar, Penerjemah Sudarsono Sudirdjo, Lily Rompans, dan Koyo Kartasurya. Jakarta: Rajawali bekerja sama dengan PAU-UT.

Djati Sidi, Indra. (2001). Menuju Masyarakat Belajar Menggagas Paradigma Bagi Pendidikan. Jakarta : Paramadina logos Wacana Ilmu.

Dede Rosyada, (2004). Paradigma Pendidikan Demokrasi, Jakarta: Kencana. 
Degeng,IN, S. (1989). Ilmu Pengajaran Taksonomi Variabel. Jakarta : Depdikbud Dikti P2LPTK.

Departemen Pendidikan dan Kebudayaan. (1994). Petunjuk Pelaksanaan Proses Belajar Mengajar. Jakarta : Rajawali.

Departemen Pendidikan dan Kebudayaan. (1955). Kurikulum Sekolah Menengah Pertama GBPP: Mata Pelajaran Sosiologi Kelas I1, III. Jakarta : Depdikbud.

Departemen Pendidikan dan Kebudayaan. (2001). Kurikulum SMP 1994 yang disempurnakan GBPP Mata Pelajaran Agama Islam Kelas III. Jakarta : Depdikbud.

Dick, W dan Carey, L (1996). The Systemathic Design of Instruction. 4th. Harper Collins Publishers.

Gagne, R.M. (1985), The Condition of Learning and Theory of Instruction(4 th edition. New York: Holt, Rineheart and Winston.

Gredler, M.E.B. Alih Bahasa Munandir. (1994). Belajar dan Mempelajarkan. Jakarta : Rajawali.

Gunawan, \& Sulasmi, E. (2020). Math Journaling in Inductive Thinking Learning Models to Enhance Students Self-Regulated Learning ( Theoretical concepts ). XXIX, 623634. https://doi.org/10.24205/03276716.2020.765

Gunawan, G., \& Sulasmi, E. (2018). Mencetak Generasi Khairu Ummah. Kumpulan Buku Dosen, 1(1).

Idrus, M. (2009). Metode Penelitian Ilmu Sosial. Jakarta: Erlangga.

Hamalik, U. (1990). Perencenaan Pengajaran. Bandung : Citra Aditya Bakti.

Hamidin. (2006). Pengaruh Model Pembelajaran Membuat Rangkuman dan Sikap Beragama Terhadap Hasil Belajar Pendidikan agama Islam SMA Negeri-1 Lawe Sigala-gala. Tesis. Pascasarjana Unimed. 2006.

Heinich, RE. (1996). Instructional Media and Technologies for Learning 5 th. New Jersey : Enggle Wood Prentice Hall.

Hartley, J. (1985). Designing Instructional. London : Kogan Page.

Joni, Raka. (1980). Strategi Belajar Mengajar. Jakarta : P2TK Ditjen Dikti

Joyce. Bruce and Well, Marsha. (1986). Models of Teaching, New Jersey: Prentice Hall, Inc.

Krech, Cruthfield And Ballchey (1962). Individual on Society. Tokyo : Mc Graw- Hill Kogakhusha

Mar'at. (1984). Sikap Munusia, Perubahan dan Pengukurunnya, Jakarta : Ghalia.

Miarso, Y., (1987) Survai Model Pengembangan Instruksional (Laporan Penelitian). DEPDIKBUD Dirjen DIKTI Proyek Pengembangan Pusat Fasilitas Bersama Antar Universitas/IUC (Bank Dunia XVII)

Morris, B.L. (1982) Learning Theoris For Teacher. New York : Harper And Row Publisher.

Nawawi, Hadari. (2004). Meningkatkan Mutu Pembelajaran Di Sekolah. Makalah. Semarang.

Popham, J.W. (1981). Modern Educational Measurement. London : Routledge and Keagen Paul.

Reigeluth, C.M. (1983). Instructional Design Theory and Models. Laurence Erlbaun Associates, New Jersey : Publisher's Hillsdale.

Sulasmi, G. E. (2020). Math Journaling in Inductive Thinking Learning Models to Enhance Students Self-Regulated Learning (Theoretical concepts). Revista Argentina de Clínica Psicológica, 29(3), 623.Sulasmi, E. (2020b). Konsep Pendidikan Humanis Dalam Pengelolaan Pendidikan Di Indonesia. 162. https://doi.org/10.1017/CBO9781107415324.004 
Sulasmi, E. (2020c). The Development Strategy of Human Resources Management In Children' s Social Welfare Institution (LKSA) (Case Study in LKSA AL-Mubaraak Orphanage Bengkulu). 562-569.

Sulasmi, E., Agussani, \& Tanjung, H. (2020). Bridging The Way Towards Sustainability Performance Through Safety, Empowerment And Learning: Using Sustainable Leadership As Driving Force. Journal Of Security And Sustainability, 9(4), 42-55.

Sulasmi, E. (2020). Cluster Program to Reduce Children's Social Resistance. Budapest International Research and Critics Institute (BIRCI-Journal): Humanities and Social Sciences, 3(4), 3686-3693.

Sulasmi, E., \& Akrim, A. (2020). Management construction of inclusion education in primary school. Talent Development and Excellence, 12(1), 334-342. 